Anna Turanskaya

Ayşe Kiliç Cengiz

Old Uyghur Blockprint of Sitātapatrā Dhārạ̣ī in the Serindia Collection of the IOM, RAS

Absract: Sitātapatrā, referred to as 'White Umbrella One' Goddess who averts evil influences and protects from all kind of disasters and malignant beings with her dhäranī. Multiple manuscripts and blockprints dedicated to this goddess, in Old Uyghur and other languages of Central Asia are stored in different world collections. This paper deals with the Old Uyghur fragments of the Sitātapatrā dhāraṇi preserved in the Serindia Collection of the Institute of Oriental Manuscripts of the Russian Academy of Sciences (IOM, RAS). These fragments refer to the same blockprint edition and this study involves the transliteration, transcription and translation of these fragments within the scope of semantic sequence.

Key words: Old Uyghur, Sitātapatrā dhāraṇī, Buddhism, blockprint, Yuan dynasty

Sitātapatrā (literally 'Goddess with the white parasol') became one of the highly honoured female deities in the Mahāyāna and Vajrayāna Buddhist traditions. The original text dedicated to the goddess Arya sarva-tathāgatauṣnīṣa-sitātapatrā-aparājitā nāma-dhāraṇī (literally 'White Umbrella One' Goddess who will protect all devotees from evil, also known under the short name Sitātapatrā dhāraṇī) was compiled in Sanskrit before 7 th c. ${ }^{1}$ Later, it was translated into numerous languages of Central $\mathrm{Asia}^{2}$ as it was regarded as a kind of protection against any negative influence of life or evil. It was

(C) Anna Turanskaya, Institute of the Oriental Manuscripts, Russian Academy of Sciences, St. Petersburg (turanskaya@mail.ru).

(C) Ayşe Kiliç Cengiz, Berlin Brandenburg Academy of Sciences and Humanities, Turfan Studies (Berlin / Germany) (kiliccengiz@bbaw.de).

${ }^{1}$ According to Prof. Sengupta, the earliest versions of the text (written in Gupta script) were found in Eastern Turkestan and date from the seventh century AD (SENGUPTA 1988, 71-72).

${ }^{2}$ For the Tibetan version, see PORCIÓ 2000, for the Chinese version see Taishō Tripitaka, vol. 19, No: 944, 945, 947, 975-977 (GieBEL 2011, 31), for Sanskrit and Khotanese versions see SANDER and WALDSChMidt 1980, 274-279; 1985, 184-185; HoERNLE 1911, 461-463; 1916, 56-57; BAiley 1963, Nr. 728 and Nr. 729. 
translated several times into Chinese, Tibetan and Mongolian. Two Sitātapatrā texts in Khotanese sources are known. ${ }^{3}$

The text became widely spread among the Old Uyghurs during the era of the Mongol empire (1206-1368). ${ }^{4}$ Vidyārājnị-sitātapatrā-sūtra (Uyg. arvišlar eligi sitatapatri sudur) probably was of great popularity among the Old Uyghurs as it was blockprinted at least two times under the patronage of the Yuan emperor's family. ${ }^{5}$ The colophons of the blockprints do not provide any information about the original text that was used for the translation, as also translators or compilers of the Old Uyghur version, date of the translation etc. ${ }^{6}$

Three fragments of one Sitātapatrā dhāraṇī blockprint in Old Uyghur are preserved in the Institute of Oriental Manuscripts of the Russian Academy of Sciences (IOM, RAS). Two separate fragments are kept under the call number SI 4502 (inv. 4558 (Old call number: M/5). They represent sixteen complete and two damaged folios of the blockprint. According to inventory book, these fragments were obtained by S.E. Malov in 1914 in Turfan city during his second expedition to Western China (1913-1915). Later, according to the note attached to the text, on July 27, 1952, they were granted (along with two other manuscripts) to the Department of Oriental Manuscripts of the Institute Oriental Studies of the Academy of Sciences of the USSR [Pl. 1]. ${ }^{7}$ These fragments were published by S.E. Malov in $1930 .^{8}$

\footnotetext{
${ }^{3}$ PORCIÓ 2003.

${ }^{4}$ The popularity of the Sitâtapatrā text is probably connected with the cult of this goddess among the Mongolian rulers. It is known that the ritual services to Sitātapatrā took place in the capital of Yuan empire Dadu during the reign of Qubilai Khan [VAn DeR KuJIP 2004, 8]. Moreover, the two Chinese translations refer to the Mongolian period (Taishō No: 976, Taishō No: 977).

${ }^{5}$ Prof. Peter Zieme was the first to notice that the fragments kept in Berlin and Russian collections are from the different blockprint editions (ZIEME 1985, 171). Some researchers assume the excistence of even more editions (PORCIÓ 2003, 93). The above mentioned editions look almost similar and differ mostly in page size. Textual collation has shown minor differences in orthography and grammar. They both have Brāhmī parts included into the text. These inserted glosses pertain to Nothern Turkistan Brāhmī (type B, subtype u) according to the Sander's classification (SANDER 1968, charts 29-40).

${ }^{6}$ The colophons of both editions were published by KASAI 2008, 121-124. According to the exterior, the fragment U 4762 that contains the complete colophon refers to the same edition of the blockprint kept in the IOM, RAS.

${ }^{7}$ The archival materials kept in the Archive of the Russian Academy of Sciences St. Petersburg Branch (where all his working and private documents are kept nowadays) do not mention where these fragments were kept since 1914. Probably they stayed in his personal archive being prepared for the publication in 1930 (cf. MALOV 1930).

${ }^{8}$ The publication includes the text printed in Uyghur script (the transliteration is absent) and translation that needs correction as the majority of the buddist terms had not been translated carefully. Moreover the article was published without a detailed archeological and codicological description or facsimile.
} 
B Uncomnum bormoxobegenus An cap (b Nerunzate)

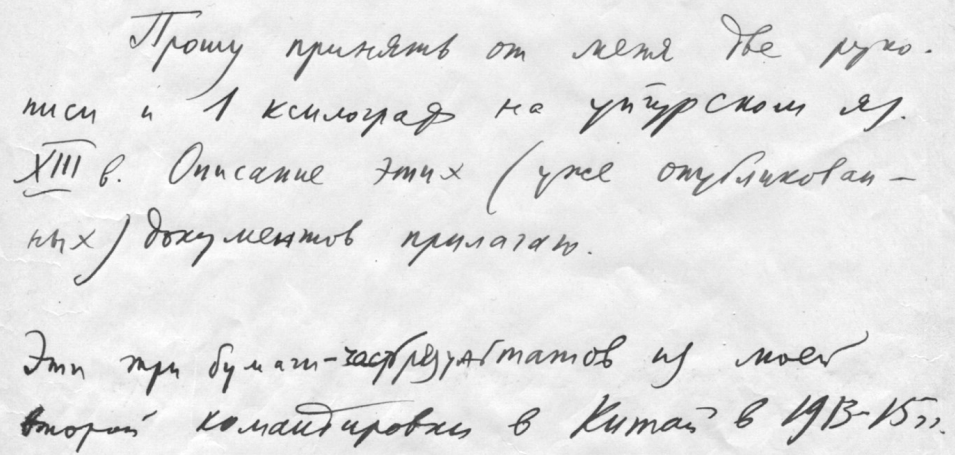
27 hons 1952 .

$$
\begin{aligned}
& \text { 7w. nopp. Ate ccop } \\
& \text { Cep. Shawb }
\end{aligned}
$$

The third fragment kept in the Serindia collection of the IOM, RAS under the call number SI 4571 (inv. 4627 (Old call number: MA/10) comprises of two folios. They are well preserved except for the fact that the left upper part of the folio with Chinese pagination 'twelve' is missing. According to inventory book, this fragment was obtained by S.E. Malov (this also attests the old called number (MA for 'Malov's collection') but the date and circumstances of acquisition are not clear. 
The fragments definetely refer to the same blockprint edition. ${ }^{9}$ The blockprint was produced in the format of 'vertical' accordion (concertina)-style book that was widespread among the Mongols and Uyghurs in the Yuan era. The size of the folded folios is $11.5 \times 28 \mathrm{~cm}(21.5 \mathrm{~cm}$ between the 'rails' denoting the upper and lower borders of the text). For production of the blockprint Chinese thin matte laid paper (4 vergé lines in $1 \mathrm{~cm}$ ) was used. The blockprint folios (printed from one wooden board) were folded two times and glued to each other (along the long edge) that is why the Chinese pagination is on every third folded page. Text is on side recto only. The folded page contains five lines of the Old Uyghur text. Interval between the text lines $-1.5 \mathrm{~cm}$.

Happened by circumstance to be the sequential parts the fragments are transcribed and transliterated in the order of the text:

\section{Transcription and Transliteration}

\section{Fragment 3}

SI 4502

[1]

01 (1) lug $y$ [ürün] ymä : yip[ün] lenh[ua köz $]^{10}-$ lwk $y[$ ] ym' : yy $p$ [ ] lynq[

02 (2) lüg : amrılmıš yavalmıš könüllü [g] ymä : lwk : 'mrylmyš y'v'lmyš kwynkwl lw[ ] ym' :

03 (3) ätöz ädgüsin biltäči ay t(ä)n[r]i y(a)ruk't'wyz 'dkw syn pylt'čy '’y tnk[ ]y yrwä

04 (4) lug : munčulayu bolar mudur kuvragları : alku lwq : mwnčwl'yw pwl'r mwdwr qwvr'ql'ry : '’lqw

05 (5) analar kuvragı birlä ymä : olar bar[ča] '’n' l'r qwvr'q y pyrl' ym' : 'wl'r p'r[ ]

\footnotetext{
${ }^{9}$ All fragments were restorated to the exhibition 'Brush and Calamus' organised to 200-years anniversary of the Asiatic museum (nowadays IOM, RAS).

${ }^{10}$ The last line of $\mathrm{U} 4658$ ( $\mathrm{T} \mathrm{I} \mu$ ) is parallel to this line; therefore, the reconstructions of yipün, lenhua and köz are in accordance with U 4658 (T I $\mu$ ).
} 


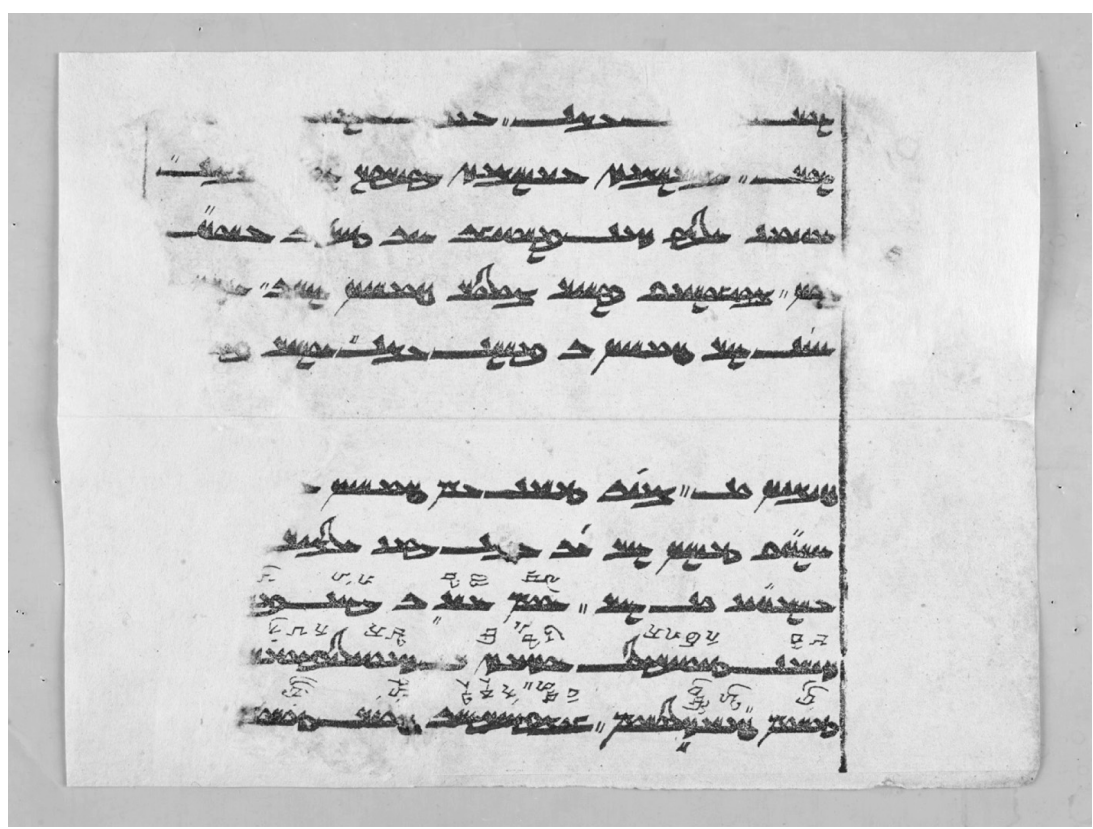

Fragment \#3

SI 4502 [1], [2]

[2]

06 (1) kamagun : meni terinim $\operatorname{kuvrag}_{l}[\mathrm{~m}][\text { birlä }]^{11}$ q'm'q wn : myniy tyryn ym qwvr'q $y[$ ] [ ]

07 (2) alku tınl(1)glarnı ymä küzädmäk [kılu] ${ }^{12}$ '’l̈̈w tynlq l'r ṅy ym' kwyz 'dm'k [ ]

08 (3) y(a)rlıkazunlar : oom erži gana pi[šastana ${ }^{13}$ yrlyä'z wn l'r : 'wwm 'yržn y k'n'’ py[ ]

09 (4) sarva tatagața ušniša sitațapatiri [hun] $]^{14}$ s'rv' t't'k'd' 'wș̌nyš ' syt'd'p'tyry [qwnk]

10 (5) turum hirišțurum : čambanakari huy turum twrwm q̈yryș̆dwrwm : č’mp'n'k'ry qwnk twrwm

${ }^{11}$ Cf. RÖHRBORN and RONA-TAŚ 2005, 261, line 163.

${ }^{12} \mathrm{Cf}$. RÖHRBORN and RONA-TAŚ 2005, 261, line 164.

${ }^{13}$ Reconstructed in accordance to the Sanskrit dhäraṇi preserved in the texts in different languages.

${ }^{14}$ Reconstructed in accordance to the Sanskrit dhärañ $\overline{~ p r e s e r v e d ~ i n ~ t h e ~ t e x t s ~ i n ~ d i f f e r e n t ~}$ languages. 


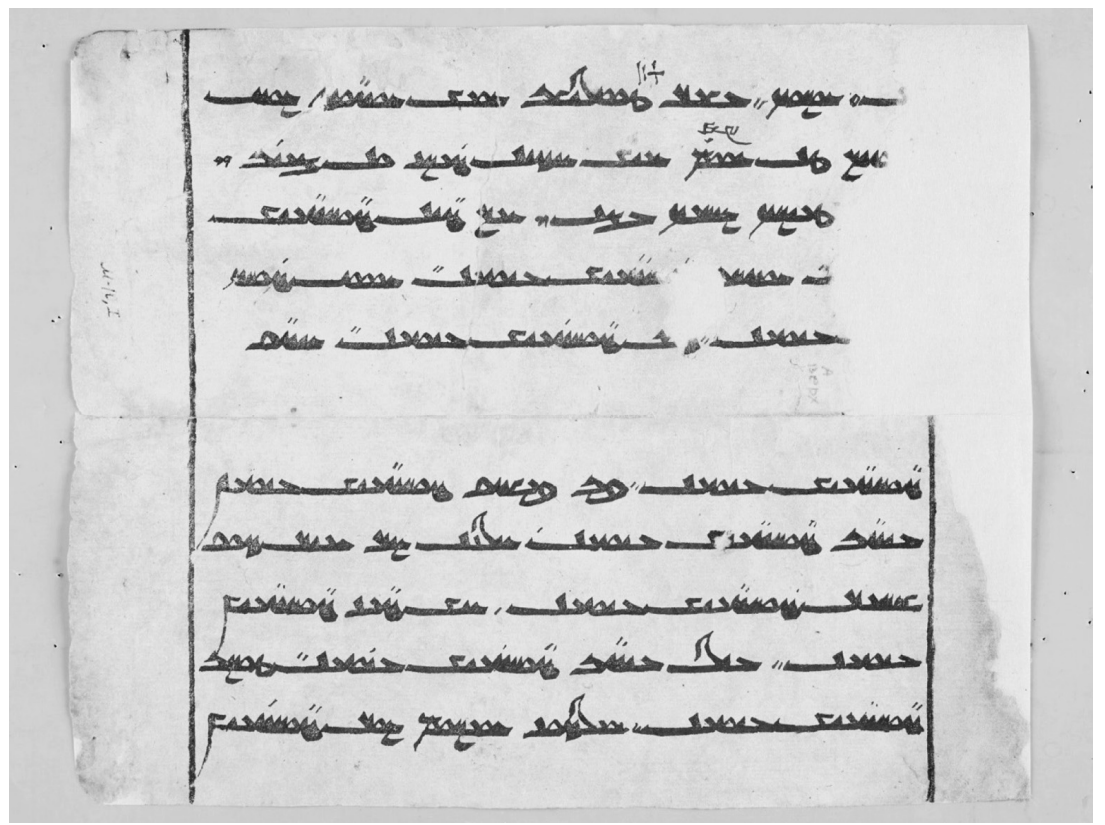

Fragment \#2

SI 4571 [1], [2]

\section{Lacuna}

\section{Fragment 2}

\section{SI 4571}

[1] ${ }^{15}$ Pagination 12 (Chin. 十二)

11 (1) [ ] ulug : v(a)čir tutdačı üč ugušlug [ ] ] 'wlwq : včyr twtd'čy 'wyč 'wäwš lwq

12 (2) [man] ḍalta ${ }^{16}$ oom enč äsän k1lzun meni :

[ ] ] t'l t' 'wwm 'ynč 's'n q̇ylz wn myñy

13 (3) [alku $]^{17} \operatorname{tınl}(1)$ glarıg ymä : el han korkınč[ ] tynlq l'ryq ym' : 'yl ä'n q̈wrq̈ynč

\footnotetext{
${ }^{15} \mathrm{U} 4472$ (o.F.) is parallel to this fragment.
}

${ }^{16}$ The reconstruction is in accordance with other versions. Here $\ddot{u ̈ c}$ ugušlug mandal 'the mandala of the three spheres' stands for Skt. tribhuvana mandala (mandal < Toh. A mandal / Toh. B mandāal < Skt. mandala ). In other versions of Sitātapatrā also have Tib. dkyil 'khor maṇụla (PORCIÓ 2000, 102, line 99); Chin. sān jièzhōng wéi (Taishō No: 977 405a 11) as its counterparts. For tribhuvana; cf. MONIER Willíams 1899, 459.

${ }^{17}$ Cf. SI 4502 [2], line 2. 
14 (4) $[\text { ıntın }]^{18}:$ ogr $l[k o]$ rkınčınt[1]n : oot kork-

[ ] : 'wqry [ ]räynč ynt[ ]n : 'wwt qंwrq

15 (5) [1nč]ıntın : suv korkınčıntın : agu

[ ] yntyn : swv q̈wrq̉ynč yntyn : ’"̈w

$[2]^{19}$

16 (1) korkınčıntın : bı bičgu korkınčıntın

q̈wrq̈ynč yntyn : py pyčqw qwrq̈ynč yntyn

17 (2) yag1 korkınčıntın : adınlarnıy süü

y'äy q̈wräynč yntyn : ' dyn l'rnynk sww

18 (3) čärig korkınčıntın : ač kız korkınč-

č’ryq q̇wräynč yntyn : ' 'č q̈yz q̈wräynč

19 (4) ıntın : yad yagı korkınčıntın tolı

yntyn : y'd y'äy q̈wrq̉ynč yn்tyn twly

20 (5) korkınčıntın : üdsüz ölümlüg korkınč

q̈wräynč yntyn : 'wydswz 'wylwm lwk q̈wrq̉ynč

\section{Fragment 3}

\section{SI 4502}

[1]

21 (1) tın yer täprämäklig korkınčtın :

tyn yyr t'pr'm'k lyk q̈wrq̈ynč tyn :

22 (2) yašın tüšmäklig korkınčtın : el-

y’šyn twyṣ̆m'k lyk q̈wrq̈ynč tyn : 'yl

23 (3) nin hannın kıy(1)n kagut korkınč-

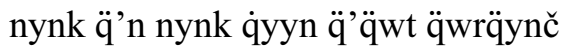

24 (4) ıntın : t(ä)yri korkınčıntın luu korkınč-

yntyn : tnkry q̈wräynč yntyn lww q̈wrq̈ynč

25 (5) ıntın : yičin : korkınčıntın : kaḍır

yntyn : yyčyn : q̈wräynč yntyn : q̈’tyr

${ }^{18}$ There is a repetitive sequences for korkınčıntın; see following lines.

${ }^{19} \mathrm{U} 4223$ (T II T 630) and U 4265 (T III 218.519) are parallel to this fragment. 


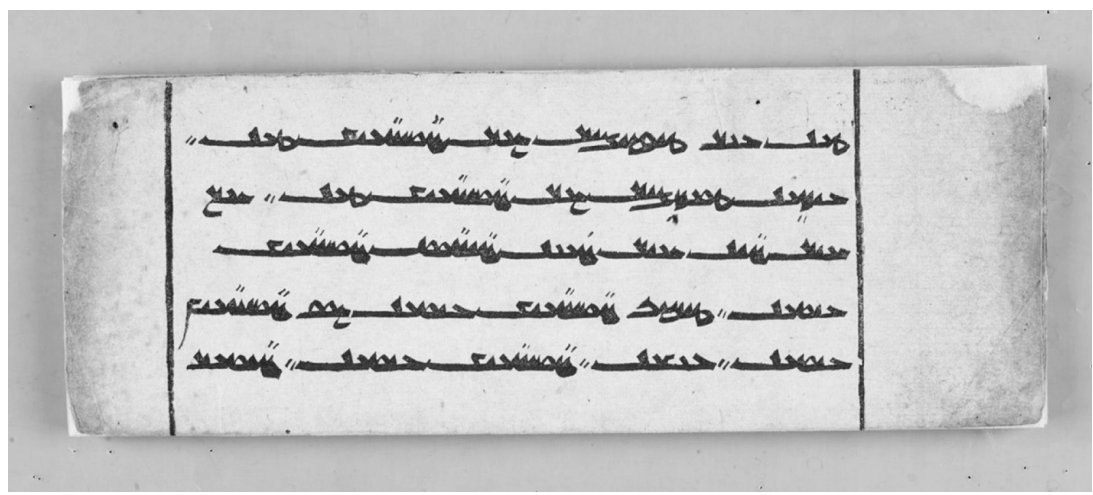

Fragment \# 3

SI 4502 [1]

$[2]^{20}$

26 (1) yavlak käyiklär korkınčıntın : isigy'vl'k k'yyk l'r q̈wräynč yntyn : 'ysyk

27 (2) kum korkınčıntın garude kuš korkınčq̈wm q̈wräynč yntyn k'rwdy q̈wš q̈wrq̈ynč

28 (3) ıntın : alku ig käm ada tuda sıkı̌ yntyn : '’l̈̈w 'yk k'm 'd' twd' syäyš

29 (4) tạıš korkınčlarıntın : yäklär korkt'nyš q̈wräyč l'r yntyn : y'k l'r q̈wrq)

30 (5) 1nčıntın : t(ä)nri tutmaktın : luu ynč yntyn : tnkry twtm'ä tyn : lww

$[3]^{21}$ Pagination: 13 (Chin. 十三)

31 (1) tutmaktın : asure tutmaktın : yäk twtm'ä tyn : ' swry twtm'ä tyn : y'k

32 (2) tutmaktın : rakšaz tutmaktın ganḍartwtm'ä tyn : r'kṣ̆’z twtm' ̈̈ tyn k'nt'r

33 (3) ve tutmaktın : garuḍe tutmaktın :

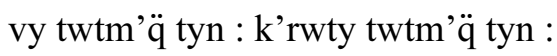

${ }^{20} \mathrm{U} 4355$ (o.F.) and U 4387 (o.F.) + U 4416 (o.F.) are parallel to this fragment.

${ }^{21}$ Some parts of U 2749 (T II M 501) and U 2752 (T II M 504) are parallel to this and following fragment. 
34 (4) marute tutmaktın : kinare tutmaktın : m'rwty twtm'ä tyn : kyń'ry twtm'ä tyn :

35 (5) mahorage tutmaktın : manuši tutmak-

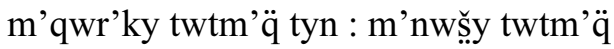

$[4]^{22}$

36 (1) tın : amanuži tutmaktın : pret tyn : 'm'nwž y twtm'ä tyn : pryt

37 (2) tutmaktın : pišače tutmaktın : kumtwtm'ä tyn : pyș 'čy twtm'ä tyn : kwm

38 (3) panḍe tutmaktın puțane tutmaktın p'nity twtm'

39 (4) katapuțane tutmaktın skanḍa tutmak-

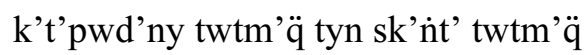

40 (5) tın utmada tutmaktın apasmar tutmaktyn 'wtm'd' twtm'ä tyn 'p'sm'r twtm'q

$[5]^{23}$

41 (1) tın čaya tutmaktın ostarake tutmaktyn č'y' twtm' ̈ tyn : 'wst'r'ky twtm'q

42 (2) tın : irevati tutmaktın : čamika tuttyn : 'yryv'ty twtm'q tyn : č'myk'

43 (3) maktın : šakuni tutmaktın : matarm'ä tyn : ș kwny twtm'q tyn : m't'r

44 (4) nandi tutmaktın : lambika tutmaktın

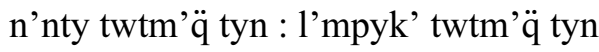

45 (5) samika tutmaktın : alambana tutmakš'myk' twtm'ä tyn : 'l'mp'n' twtm'ä

\footnotetext{
${ }^{22} \mathrm{U} 4633$ (T II D) is also parallel to this fragment.

$23 * \mathrm{U} 9206$ (T III M 182) (1) is parallel to this fragment. For a long time it was considered that these $* U$ fragments belong to the losses during World War II but now these fragments have been 're-discovered' in the storage of State Hermitage (for *U fragments, cf. PCHELiN and RASCHMANN 2016, 13-14, 23-24).
} 


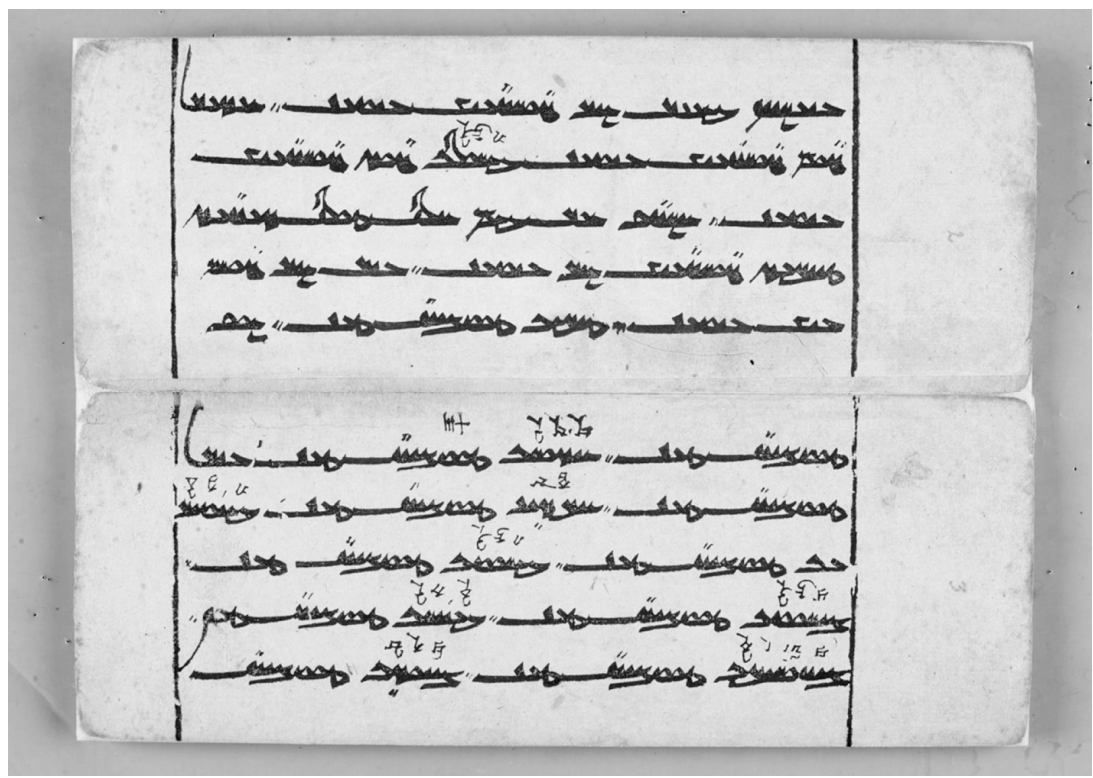

Fragment \#3

SI 4502 [2], [3]

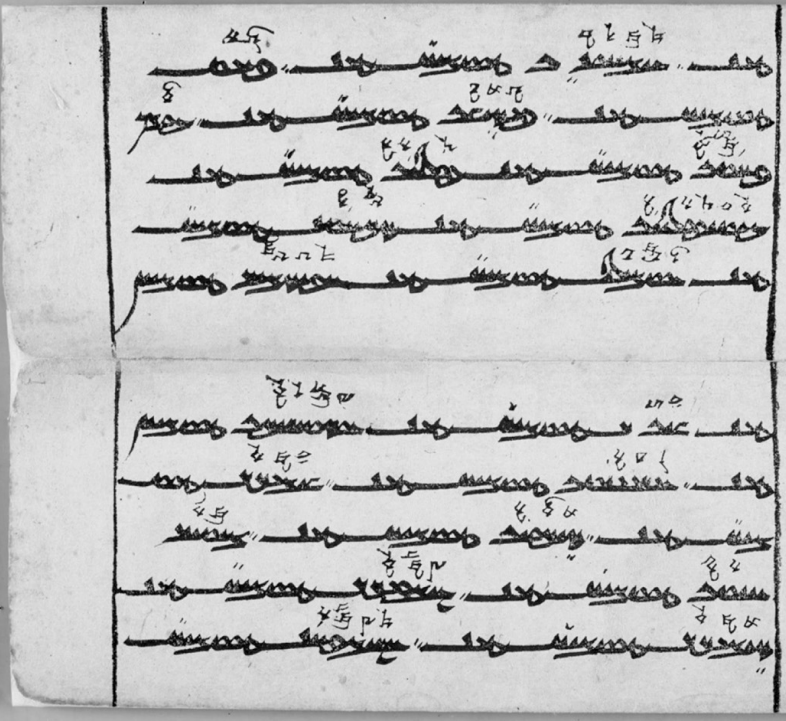

Fragment \#3

SI 4502 [4], [5] 

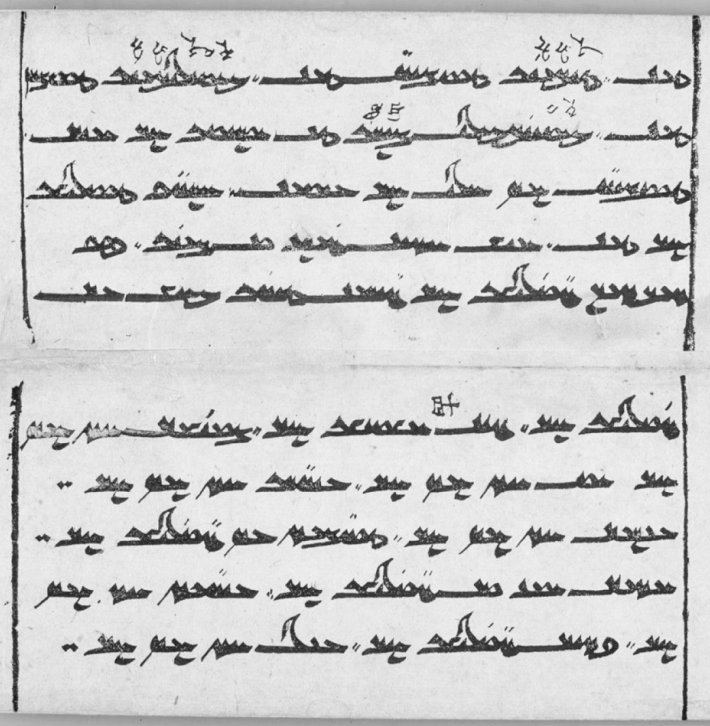

Fragment \#3

SI 4502 [6], [7]

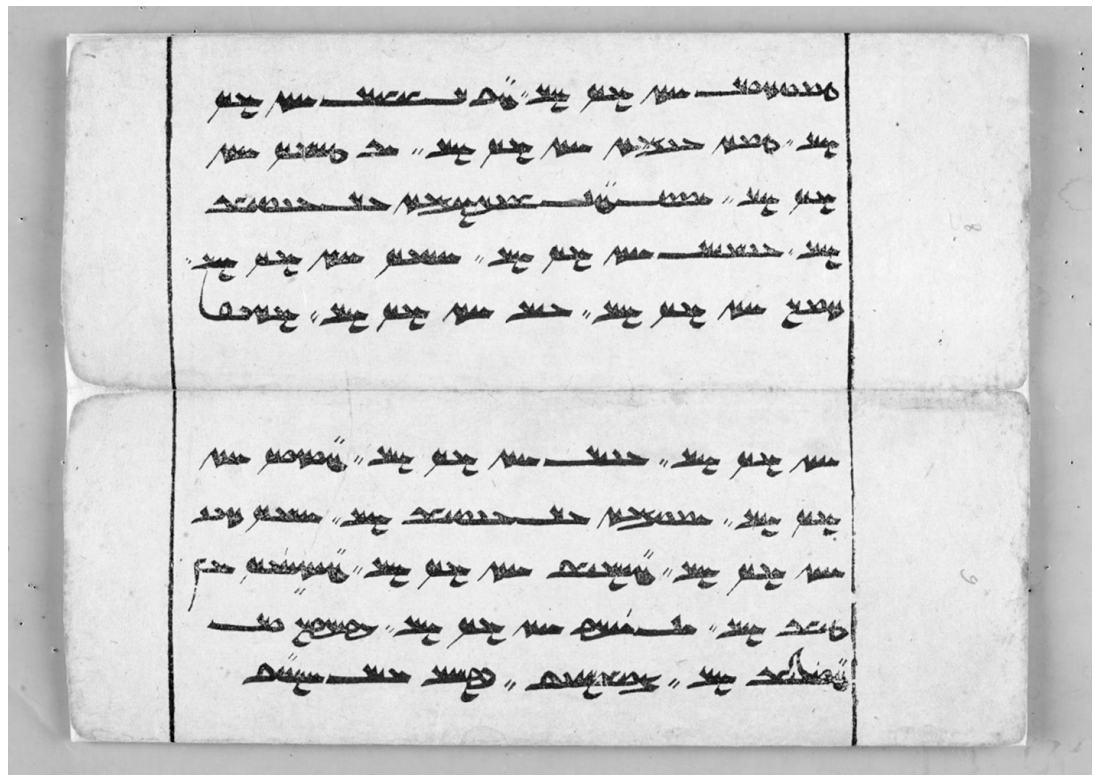

Fragment \#3

SI 4502 [8], [9] 
$[6]^{24}$

46 (1) tın : ḍakini tutmaktın : katadakini tutmak-

tyn : t'kyny twtm'ä tyn : k't'd'kyny twtm'q

47 (2) tın : katankața malita ulatılarnın

tyn : k't'nikk'd' m'ly t' 'wl'ty l'r nynk

48 (3) tutmaklıg adalarıntın : alku tutdačı-

twtm'ä lyq ',d' l'r yntyn : 'läw twtd'čy

48 (4) lartın : enč äsän kılzun meni : boo

l'r tyn : 'ynč 's'n q̇ylz wn myñy : pww

50 (5) sigšil kundačılar karıntakı känčig sykšyl q̈wṅd'čy l'r q̈'ryn t'äy k'nč yk

$[7]^{25}$ Pagination 14 (Chin. 十四)

51 (1) kundačllar : kan ičtäčilär : münčik ašlıgquwnd'čy l'r : q'n 'yčt'čy l'r : mwyñčyk "'š lyq

52 (2) lar ät ašlıg-lar : yakrı ašlıglar :

l'r 't 'š lyq l'r : y'äry ', š lyq l'r :

53 (3) yilik ašlıglar : tugmıšıg kundačılar :

yylyk "š lyq l'r : twämyš yq q̈wṅd'čy l'r :

54 (4) isig özüg kundačılar : yagıš ašlıg'ysyk 'wyz wk q̈wñd'čy l'r : y'äyš ',š lyq

55 (5) lar : psak kundačılar : yıd ašlıglar :

l'r : ps'k q̈wñd'čy l'r : yyd '’̌ lyq l'r :

$[8]^{26}$

56 (1) tütsüg ašlıglar : hua čäčäk ašlıgtwytswk "'š lyq l'r : ̈̈w ' č'č'k 'š lyq

57 (2) lar : tüš yemiš ašlıglar : 1 tarıg aš-

l'r : twyš yymyš "'š lyq l'r : 'y t'ryq '’̌

$24 * \mathrm{U} 9206$ (T III M 182) (2) is parallel to this fragment.

$25 * \mathrm{U} 9207$ (T III M 231) (1) is parallel to this fragment (see PCHELin and RASchmanN, 2016: 24; LE COQ, 1919: 106). Some parts of U 4611 (o.F.) and U 4716 (T III M 225) are parallel to this and following fragment with a different line or word sequence.

$26 * \mathrm{U} 9207$ (T III M 231) (2) is parallel to this fragment. 
58 (3) liglar : ootka čöklämišig yetäčilyq l'r : 'wwt q̈' čwykl'myš yk yyt'čy

59 (4) lär : yirin ašlıglar : akıg ašlıglar :

l'r : yyrynk "š lyq l'r : "qyq "š lyq l'r :

60 (5) söl ašlıglar : yar ašlıglar : lešip

swyl '’š lyq l'r : y'r '’š lyq l'r : lyšyp

$[9]^{27}$

61 1. ašlıglar : yin ašlıglar : kusok aš-

"'š lyq l'r : yynk "š lyq l'r : q̈wswq "'s

62 2. liglar : ötmišig yetäčilär : arıgsız

lyq l'r : 'wytmyš yk yyt'čy l'r : 'ryq syz

63 3. ašlıglar : kalınču ašlılar : kašanıg ič-

, 'š lyq l'r : ä'lynčw "š lyq l'r : ä’š̀nyq 'yč

64 4. täčilär : nä nägü ašliglar : köyülüg

t'čy l'r : n' n'kw '’š lyq l'r : kwnkwl wk

65 5. kundačılar : munčulayu : bolarnı̉ alku

q̈wṅd'čy l'r : mwnčwl'yw : pwl'r nynk '’lq̈w

$[\mathbf{1 0}]^{28}$

66 (1) kamag butelarnıj k1lmıš yaratmıš arvı̌̌q'm'q pwty l'r nynk qylmyš y'r'tmyš ' 'rvyš

67 (2) ların k1lıč üzä käsär m(ä)n v(a)čir üzä l'ryn qylyč 'wyz ' k's'r mn včyr 'wyz'

68 (3) kažgok tokıyur m(ä)n : hormuzta üzä ymä q̈'sq̈wä twq்yywr mn : qwrmwz t' 'wyz ' ym'

69 (4) k1lılmıš arvıšın käsär m(ä)n kazgok tok1qylylmyš ',rvyš yn k's'r mn q̈'sq̈wä twqy

70 (5) yur m(ä)n : ḍakadakinilarnın kılmıš arvıšywr mn : t'k'd'kyny l'r nynk qylmyš ',rvyš

\footnotetext{
$27 *$ U 9207 (T III M 231) (3) is parallel to this fragment.

$28 * \mathrm{U} 9207$ (T III M 231) (4) is parallel to this fragment.
} 


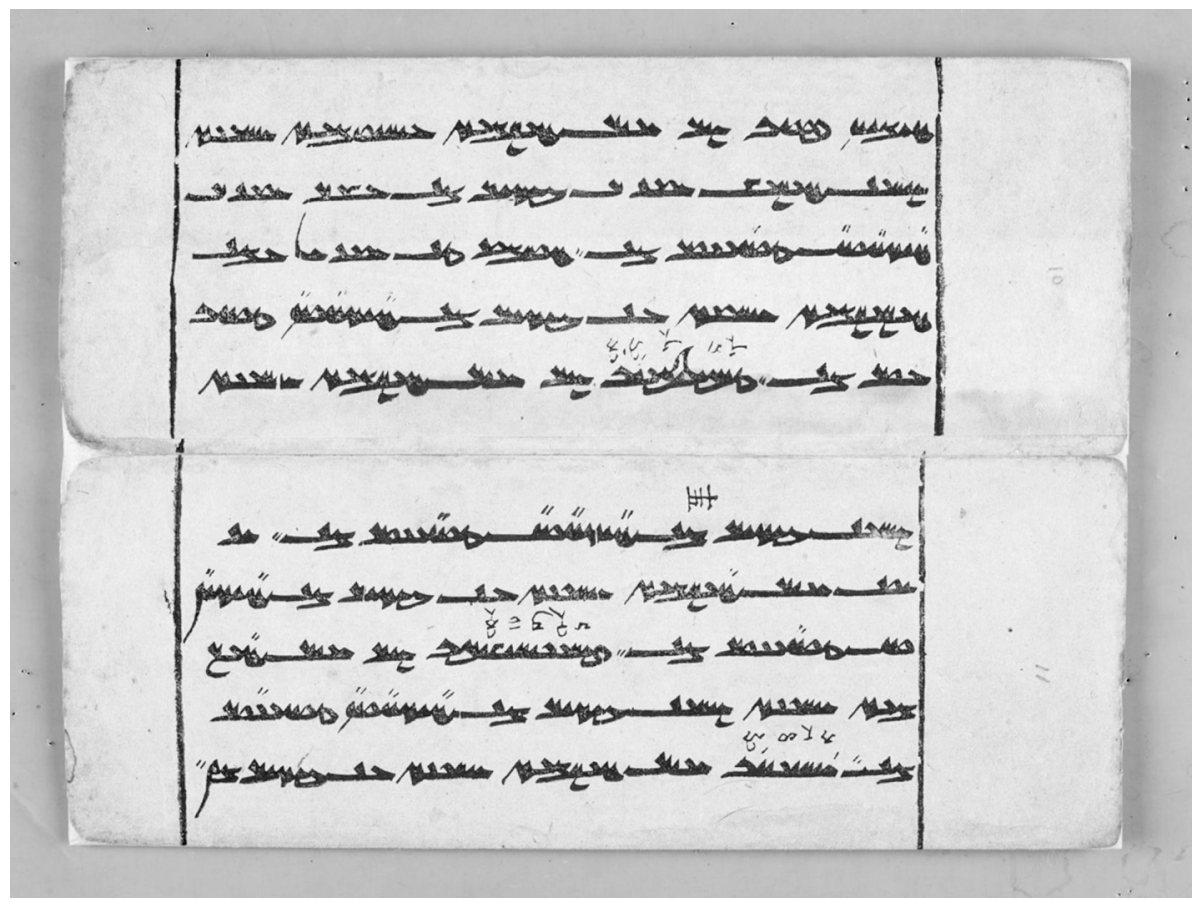

Fragment \#3

SI 4502 [10], [11]

[11] ${ }^{29}$ Pagination: 15 (Chin. 十五 shi wu)

71 (1) ların käsär m(ä)n kaẓgok tokıyur m(ä)n : äzl'ryn k's'r mn ä'sq̈wq̈ twäyywr mn 'z

72 (2) rua-nın kılmıš arvıšın käsär m(ä)n kazgrw' nynk äylmyš ' 'rvyš yn k's'r mn q̈'sä

73 (3) ok tokıyur m(ä)n : parivaračakelarnın k1lwq twäyywr mn : p'ryv'r'č'ky l'r nynk q̈yl

74 (4) mıš arvıšların käsär m(ä)n kaẓgok tokıyur myš ' 'rvyš l'ryn k's'r mn q̈'säwä twqyywr

75 (5) m(ä)n : narayanenın kılmıš arvıšın käsär m(ä)n : mn n்'r'y'ñy nynk qylmyš ',rvyš yn k's'r mn :

${ }^{29}$ U 390 (T III M 225 (59)) and U 4658 (T I M) are parallel to this fragment. 


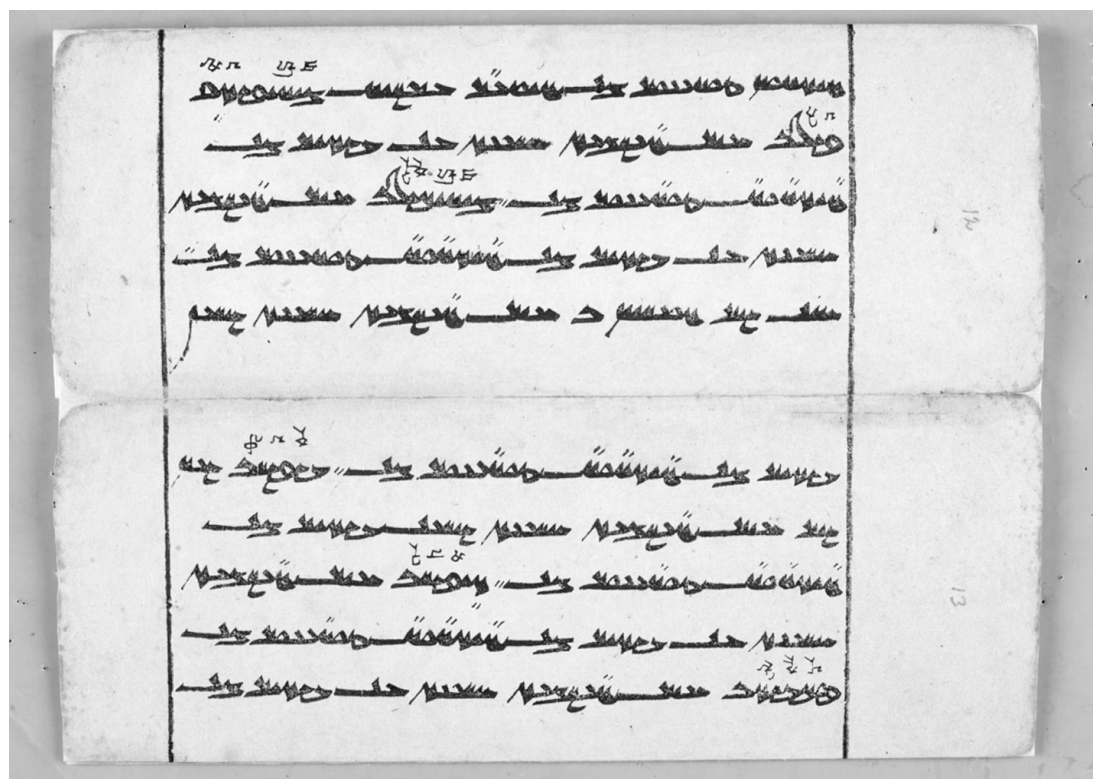

Fragment \#3

SI 4502 [12], [13]

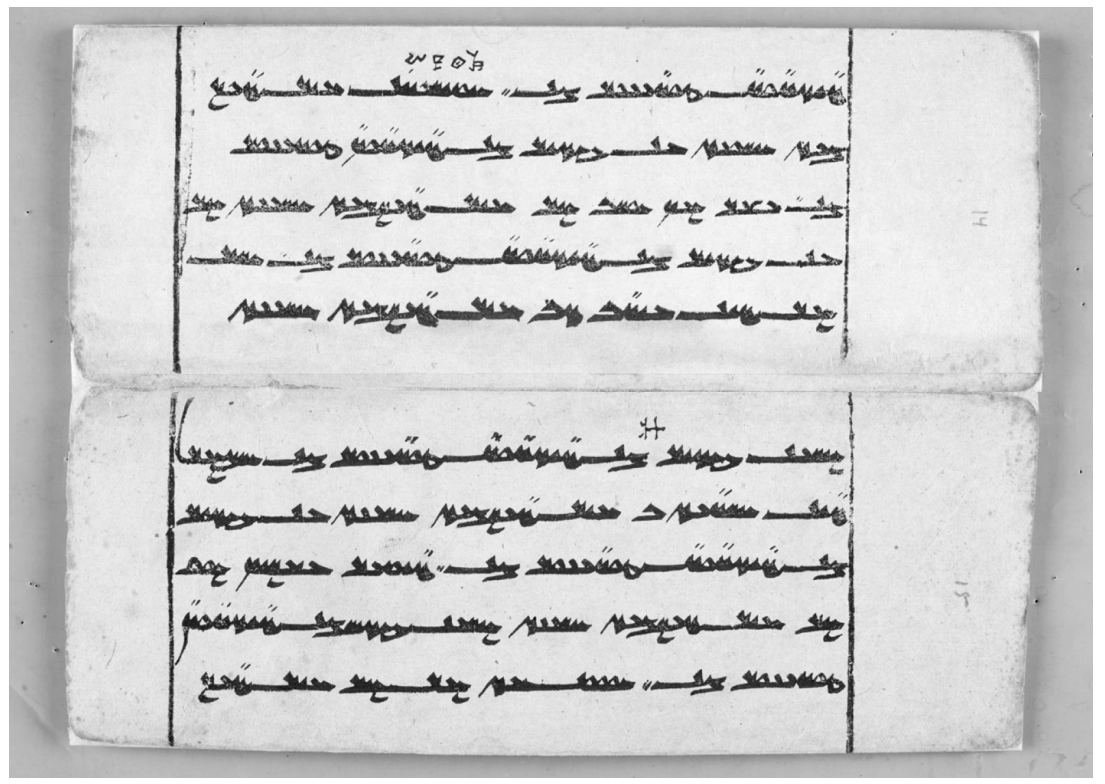

Fragment \#3

SI 4502 [14], [15] 
[12]

76 (1) kazgok tokıyur m(ä)n kaḍır yavlak mahapašuq'sqwq twqyywr mn q̈'tyr y'vl'q m'q'p'ṣ̌w

77 (2) paținın kılmıš arvıšın käsär m(ä)n p'dy nynk äylmyš ' 'rvyš yn k's'r mn

78 (3) kazgok tokıyur m(ä)n : mahakadenıy kılmıš q̈'sq̈wq̈ twäyywr mn : m'q'k'dy nynk äylmyš

79 (4) arvıšın käsär m(ä)n kazgok tokıyur m(ä)n : '’rvyš yn k's'r mn q̈'sq̈wq̈ twkyywr mn :

80 (5) analar ${ }^{30}$ kuvragının kılmıš arvıšların '’n' l'r qwvr'q y nynk q̈ylmyš ’'rvyš l'ryn

\section{[13]}

81 (1) käsär m(ä)n kazgok tokıyur m(ä)n : kapalilıgk's'r mn q̈'sq̈wq̈ twäyywr mn : k'p'ly lyq

82 (2) larnın kılmıš arvıšların käsär m(ä)n l'r nynk q̈ylmyš "'rvyš l'ryn k's'r mn

83 (3) kazgok tokıyur m(ä)n : šabarinıj kılmıš q̈'sq̈wq̈ twäyywr mn : ș’p'ry nynk q̈ylmyš

84 (4) arvıšın käsär m(ä)n kaẓgok tokıyur m(ä)n "'rvyš yn k's'r mn ä'sq̈wä twäyywr mn

85 (5) bukkakasinin ${ }^{31}$ k1lmıš arvıšın käsär m(ä)n pwkk'k'sy nynk äylmyš '’rvyš yn k's'r mn

\section{[14]}

86 (1) kazgok tokıyur m(ä)n : atarvananın kı1q̈'sq̈wä twäyywr mn : 't'rv'n'' nynk q̈yl

87 (2) mıš arvıšın käsär m(ä)n kazgok tokıyur myš ' 'rvyš yn k's'r mn q̈'sq̈wä twäyywr

88 (3) m(ä)n : v(a)čirlıg urılarnıy kılmıš arvıšlarmn : včyr lyq 'wry l'r nynk q̈ylmyš "'rvyš l'r

89 (4) ın käsär m(ä)n kazgok tokıyur m(ä)n : ärk yn k's'r mn q̈'säwä twäyywr mn : 'rk

90 (5) lig han yagısının kılmıš arvıšlyk q'n y' q̈y sy nynk q̈ylmyš ',rvyš

\footnotetext{
${ }^{30}$ Malov 1930, 91 :

${ }^{31}$ MALOV 1930, 91: wryerves "pwkk'k'sy".
} 


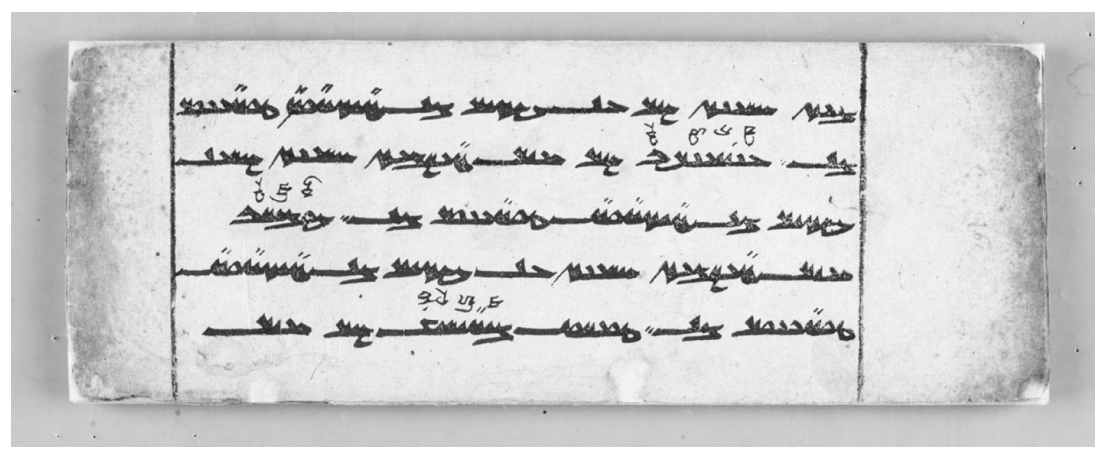

Fragment \#3

SI 4502 [16]

[15] Pagination 16 (Chin. 十六 shi liu)

91 (1) ların käsär m(ä)n kazgok tokıyur ${ }^{32}$ m(ä)n ärklig l'ryn k's'r mn q̈'sq̈wä twäyywr mn 'rklyk

92 (2) han arkıšının kılmıš arvıšın käsär q̈'n 'räyš y nynk äylmyš ' rvyš yn k's'r

93 (3) m(ä)n kazgok tokıyur m(ä)n : kaḍır yavlak luumn q̈'sq̈wä twäyywr mn : q̈'tyr y'vl'q lww

94 (4) larnın kılmıš arvıšın käsär m(ä)n kazgok l'r nynk qylmyš ',rvyš yn k's'r mn q̈'sq̈wq̈

95 (5) tokıyur m(ä)n : oot išliglärnin k1ltwäyywr mn : 'wwt'yš lyk l'r nynk q̈yl

[16]

96 (1) mıš arvıšların käsär m(ä)n kazgok tokıyur myš " rvyš l'r yn k's'r mn ä'säwä twäyywr

97 (2) m(ä)n : vinayikelarnın kılmıš arvıšların mn : vyñ'yyky l'r nynk äylmyš ' 'rvyš l'ryn

98 (3) käsär m(ä)n kaẓgok tokıyur m(ä)n : kumare k's'r mn ä'sq̈wq̈ twäyywr mn : kwm'ry

99 (4) nın kılmıš arvıšın käsär m(ä)n kazgok nynk äylmyš ',rvyš yn k's'r mn q̈'sq̈wä

100 (5) tokıyur m(ä)n : tört maharačlarnın twäyywr mn : twyrt m'ä'r'č l'r nynk

\footnotetext{
${ }^{32}$ MALOV 1930, 91: مصندم: "twäyyw”.
} 


\section{Translation}

(01-08) [Sitātapatrā is... with charming eyes] and white, with violet lotus-eyes, with calm and peaceful mind, posessing knowledge of the virtue of the soul, shining like a moon-god (Chandraprabha?). May this groups of mudrās together with hosts of mātṛs protect me and my community and all sentient beings and deign this way. (08-10) Oṃ ṛ̣i-gana-prașastana-sarvatathāgatoṣnīṣa-sitātapatre hūṃ țrūṃ hrī șṭom jambhanakari hūṃ ṭrūṃ (1113) $[. .$.$] the great vajradhāra in the mandala of the three spheres! Om!$ Bestow me and all sentient beings tranquility and health! (13-30) [Protect me and all sentient beings] from the fear of the king, from the fear of robbers, from the fear of fire, from the fear of water, from the fear of poison, from the fear of weapons, from the fear of enemies, from the fear of enemy troops, from the fear of famine, from the fear of foreign enemies, from the fear of hail, from the fear of untimely death, from the fear of earthquake, from the fear of falling thunderbolt, from the fear of being punished by state and rulers, from the fear of the gods, from the fear of naggas, from the fear of lightning, from the fear of ferocious furios animals, from the fear of hot sand [deserts], from the fear of bird Garuda, from the fear of all diseases and illnesses, misfortunes and afflictions, from the fear of demons, (30-48) from the [danger of] possession of devas, possession of nāgas, possession of asuras, possession of demons, possession of rākșas, possession of gandharvas, garudas, possession of marutas, possession of kinnaras, possession of mahoragas, possession of manušya, from the possession of amanușyas, from the possession of pretas, from the possession of piśācas, from the possession of kumbhāndas, from the possession of pütanas, from the possession of katapütanas, from the possession of skandas, from the possession of unmādas, from the possession of apasmāras, from the possession of chāyas, from the possession of ostârakas, from the possession of revatīs, from the possession of jāmikās, from the possession of siakuniss, from the possession of mātrnandịs, from the possession of lambikās, from the possession of samikas, from the possession of àlambhanas, possession of dakiniss, possession of kața-d̄ākinīs, possession of katankata-mālis etc., possession of all other grasper-demons, may [the dhāranīi give me peace and tranquility from the dangers. (48-55) The vigour-stealers, the fetus-snatchers [from mother's] womb, the blood-drinkers, the clot-eaters, the flesh-eaters, the fat eaters, the marrow-eaters, the newborn-stealers, the life-stealers, the offerings-eaters, the garland-stealers, (55-65) the fragnance-eaters, the incense-eaters, the 
flowers-eaters, the fruits-eaters, the crops-eaters, the burnt offering-eaters, the pus-eaters, the discharge-eaters, the spittle-eaters, the saliva-eaters, the phlegm-eaters, the slime-eaters, the vomit-eaters, the excrement(?)-eaters, the impurity-eaters, the [food] residue-eaters, the urine-drinkers, everythingeaters, the consciousness-stealers; (65-100) in this way I cut off with a sword the spells performed by all of these [demons] and all bhütas and I nail them down with a vajra. I cut off the spells also performed by Indra and nail them down. I cut off the spells performed by dẹkas and dākinīs and nail them down. I cut off the spells performed by Brahma and nail them down. I cut off the spells performed by parivrajjakas and nail them down. I cut off the spells performed by Närāyaṇa and nail them down. I cut off the spells performed by fierce and ferocious Mahāpaśupati and nail them down. I cut off the spells performed by Mahākāla and nail them down. I cut off the spells performed by host of mātrs and nail them down. I cut off the magics performed by Kāpälikas and nail them down. I cut off the spells performed by Śavari and nail them down. I cut off the magics performed by Pukkasa and nail them down. I cut off the spells performed by Atharvana and nail them down. I cut off the spells performed by Vajrakaumāri and nail them down. I cut off the spells performed by Yamantaka and nail them down. I cut off the spells performed by the messenger of Yama and nail them down. I cut off the spells performed by ferocious nāgas and nail them down I cut off the spells performed by agnikarmins ${ }^{33}$ and nail them down. I cut off the spells performed by vinayyakas and nail them down. I cut off the spells performed by Kumāra and nail them down. [I cut off the spells performed by] four Mahārājas [and nail them down...]

\section{References}

ADAms, Douglas Q. 2013: A Dictionary of Tocharian B - Revised and Enlarged. Amsterdam-New York: Rodopi.

BAILEY, Harold Walter 1963: Indo-Scythian Studies: Being Khotanese Texts Volume V. New York: Cambridge University Press.

GIEBEL, Rolf W. 2011: "Taishō Volumes 18-21". In: Esoteric Buddhism and the Tantras in East Asia (ed. by C.D. Orzech). Handbook of Oriental Studies, Section 4 (China), 24, Leiden: Brill, 27-36.

HoERnLE, A.F. Rudolf 1911: “The 'Unknown Languages' of Eastern Turkestan. II". The Journal of the Royal Asiatic Society, 43/2, April, 447-477.

\footnotetext{
${ }^{33}$ Lit. engaged in fire actions.
} 
HoERnLE, A.F. Rudolf 1916: Manuscript Remains of Buddhist Literature Found in Eastern Turkestan, Facsimiles with Transcripts Traslations and Notes, vol. I. Oxford: The Clarendon Press.

KASAI, Yukiyo 2008: Die uigurischen buddhistischen Kolophone. Berliner Turfantexte XXVI. Turnhout: Brepols.

Le Coq, Albert von 1919: "Kurze Einführung in die uigurische Schriftkunde". Mitteilungen des Seminars für Orientalische Sprachen an der F. Wilhelms-Universität in Berlin 22/2, 93-109.

MALov, Sergej Efimovich 1930: "Sitātapatrā-dhāraṇ̄ v ujgurskoj redakcii”. Doklady Akademii nauk SSSR 5. Moscow, 88-94.

Monier Williams, S. Monier 1899: A Sanskrit-English Dictionary, Etymologically and Philologically Arranged with Special Reference to Cognate Indo-European Languages. Oxford.

Pchelin, Nikolaj and Raschmann, Simone-Christiane 2016: "Turfan Manuscripts in the State Hermitage - a Rediscovery". Written Monuments of the Orient 2(4), 3-44.

Porció, Tibor 2000: The One with the White Parasol, Four Sitātapatrā Texts in the Derge Kanjur and a Dunhuang Text (Pelliot Tibétain No. 45) with an Annotated English Translation of the Longest Canonical Version. Faculty of Arts of the University of Vienna. Vienna.

Porció, Tibor 2003: "On the Brāhmī Glosses of the Uygur Sitātapatrā Text". Central Asiatic Journal, vol. 47, no. 1, 91-109.

PouchA, Pavel 1955: Thesaurus Linguae Tocharicae Dialecti A. Praha: Státní Pedagogické Nakladatelství.

SANDER, Lore 1968: Paläographisches zu den Sanskrithandschriften der Berliner Turfansammlung. Wiesbaden: Franz Steiner Verlag.

SANDER, Lore, Waldschmidt, E. (1980): Sanskrit Handschriften aus den Turfanfunden. Teil IV. Ergänzungsband zu Teil 1-3 mit Textwiedergaben, Berichtigungen und Wörterverzeichnissen (Verzeichnis der Orientalischen Handschriften in Deutschland 10, 4). Wiesbaden: Franz Steiner Verlag.

SANDER, Lore and WALDSCHMIDT, Ernst 1985: Sanskrit Handschriften aus den Turfanfunden. Teil V. Die Katalognummern 1015-1201 und 63 vorweggenommene höhere Nummern (Verzeichnis der Orientalischen Handschriften in Deutschland 5). Stuttgart: Franz Steiner Verlag.

SENGUPTA, Shantanu 1988 (1974): “A Note on Uș̣ị̄ṣa-Sitātapatrā — pratyaṃgira Dhāran̄̄”. Buddhist Studies I. Delhi, 70-77.

Taishō = Taishō Shinsū Daizōkyō (大正新脩大藏經). http://21dzk.1.u-tokyo.ac.jp/SAT/ index_en.html.

VAN DER KuJIP, Leonard 2004: "The Kālacakra and the Patronage of Tibetan Buddhism by the Mongol Imperial Family". In: The Central Eurasian Studies Lectures 4. Bloomington: Indiana University.

ZIEME, Peter 1985: Buddhistische Stabreimdichtungen der Uiguren. Berliner Turfantexte XIII. Berlin: Akademie Verlag. 